Matgorzata Pamula-Behrens

AgniesZKa HENNEL-BRZOZOWSKA

Uniwersytet Pedagogiczny im. Komisji Edukacji Narodowej

$w$ Krakowie

\title{
OSOBOWOŚĆ NAUCZYCIELI \\ A PRACA Z DZIEĆMI MIGRANTAMI \\ W SZKOLE PODSTAWOWEJ
}

AвsTract. Pamuła-Behrens Małgorzata, Hennel-Brzozowska Agnieszka, Osobowość nauczycieli a ich praca z dziećmi migrantami w szkole podstawowej [The Teacher's Personality and its Impact on Work with Migrant Children in the Primary School]. Studia Edukacyjne nr 46, 2017, Poznań 2017, pp. 169-191. Adam Mickiewicz University Press. ISSN 1233-6688. DOI: 10.14746/se.2017.46.11

Research on the personality of primary school teachers and on their level of competence in teaching migrant children, including their own migration experience and their attitudes toward training for better education of foreign pupils, was conducted in 2016, using Big Five NEO-FFI and a questionnaire constructed by the authors (PPNUC). The subjects work in a big Polish city and their school is attended by Ukrainian and Vietnamese migrant children; half of the teachers (called NU) have the migrant children in their classes, the other half do not (NN). The results have shown, among others, that NU teachers have higher extraversion scores than NN and that younger teachers have a more positive attitude toward training programs for educating migrant children.

Key words: migrant children, migrant education, teacher personality, Big Five, Vietnamese migrants, Ukrainian migrants

\section{Wstęp}

Edukacja polska stoi wobec wyzwania zapewnienia wsparcia w szkołach i udzielenia pomocy dzieciom $\mathrm{z}$ doświadczeniem migracji $\mathrm{w}$ procesie uczenia się i integracji. Dzieci takich przybywa w polskich szkołach i nauczyciele, ich kompetencje oraz postawy są kluczowe w procesie ich edukacji, bo warunkują $\mathrm{w}$ dużym stopniu sukcesy szkolne tych dzieci. Widząc konieczność adaptacji szkoły do nowego kontekstu, podjęłyśmy badania nad postawami nauczycieli wobec wybranych współczesnych zjawisk społecznych, a kon- 
kretnie - wobec edukacji dzieci migrantów. Postawy są sposobem reagowania (pozytywnego lub negatywnego) danej jednostki na osobę, grupę osób, instytucję, czy też wydarzenie. Jednym z czynników warunkujących postawy wobec innych jest osobowość. W myśl personalistycznej koncepcji postaw, cechy osobowości są kształtowane przez wpływ i kontakty społeczne oraz doświadczenie. W naszym badaniu, które realizowane jest $w$ dwóch etapach: pilotażowym (2016 rok) i zasadniczym (rok szkolny 2016/2017) chcemy zbadać, jakie czynniki, w tym i sama osobowość, warunkują te postawy. Badania mają także na celu sprawdzenie, czy i w jakim stopniu doświadczenie pracy z uczniem cudzoziemskim wpływa na postawy nauczycieli wobec tych dzieci. Chcemy ustalić, czy istnieją cechy osobowości warunkujące postawy (pozytywne jak i negatywne) wobec uczniów migrantów oraz czy istnieje korelacja między ich postawami i deklarowanymi zachowaniami a tymi cechami. Niniejszy tekst przedstawia zarys problemu oraz część wyników badania pilotażowego. Badanie zasadnicze przyniesie więcej twardych danych na temat korelacji między postawami wobec dzieci migrantów a osobowością nauczycieli. Mamy nadzieję, że nasza refleksja i badania będą przyczynkiem do dyskusji i zmian w programach przygotowania przyszłych nauczycieli oraz form doskonalenia zawodowego czynnych nauczycieli, aby lepiej przygotowywały nauczycieli do pracy w środowisku wielokulturowym.

\section{Problematyka badawcza Postawy Polaków wobec migrantów - aktualne badania}

W ostatnich latach w większości krajów OECD wzrasta lawinowo liczba migrantów i uchodźców. Jak pokazują europejskie dane statystyczne, tendencja ta dotyczy także Polski. Zwiększenie się liczby cudzoziemców wpływa również bezpośrednio na polską edukację. Jak podaje Urząd do Spraw Cudzoziemców,

od 1 stycznia 2014 r. do końca kwietnia 2015 r. o nadanie statusu uchodźcy w RP ubiegało się 10801 cudzoziemców - o 29\% mniej niż w rekordowym 2013 roku. Tradycyjnie najwięcej potencjalnych uchodźców pochodziło z Rosji $(90 \%$ z nich deklarowało narodowość czeczeńską). Drugie miejsce zajmują obywatele Ukrainy, którzy w ciągu ostatnich 16 miesięcy ubiegali się o ochronę międzynarodową na niespotykaną dotychczas skalę. 91\% spośród nich deklarowało narodowość ukraińską. (...) Poza tym powyżej 100 osób ubiegających się o nadanie statusu uchodźcy pochodziło jeszcze z: Armenii, Syrii, Tadżykistanu i Kirgistanu ${ }^{1}$.

1 Urząd do Spraw Cudzoziemców, Naptyw cudzoziemców ubiegających się o objęcie ochrona międzynarodowa do Polski w latach 2009-2015, raport http://udsc.gov.pl/wp-content/ uploads/2015/05/refugee-report.pdf [dostęp: 6.01.2016]. 
Rzeczniczka Urzędu poinformowała także, że w latach 2007-2015 prawie 373 tysiące cudzoziemców złożyło wnioski o udzielenie im zgody na zamieszkanie w Polsce na pobyt czasowy. Najliczniejsze grupy wśród tych cudzoziemców to obywatele: Ukrainy (140 tys.), Wietnamu (26,5 tys.), Chin (23,5 tys.), Białorusi (20 tys.) i Federacji Rosyjskiej (16 tys.). Podkreśliła, że w omawianym okresie obserwuje się „stałą tendencję wzrostu liczby cudzoziemców korzystających w Polsce z tej formy legalizacji pobytu". W tej złożonej sytuacji nauczyciele stają wobec nowych wyzwań, bo coraz częściej uczą w klasach, gdzie wśród uczniów znajdują się dzieci z doświadczeniem migracji. Konieczne jest podejmowanie przez nich działań wspierających integrację nowo przybyłych, ponieważ badania pokazują, że jednym z najistotniejszych elementów udanej integracji jest dobre poznanie przez dziecko kultury i języka, którym posługuje się w szkole ${ }^{2}$. Niedobory w tym zakresie są przyczyną wielu porażek szkolnych, opuszczania przez dzieci systemu edukacji oraz bardzo niskie kwalifikacje wielu migrantów. Jednocześnie badacze zwracają uwagę na rolę nauczycieli w procesie edukacji dzieci z doświadczeniami migracji. Obserwuje się, że przyczyną porażek szkolnych tych dzieci są negatywne postawy nauczycieli wobec dzieci migrantów.

Nauczycielskie postawy należy jednak interpretować w szerszym kontekście - postaw Polaków w stosunku do migrantów i uchodźców. Nauczyciele są częścią społeczeństwa i ich postawy odzwierciedlają tendencje społeczne. W niniejszym tekście prezentujemy badania dotyczące postaw Polaków wobec cudzoziemców: Międzynarodowej Organizacji ds. Migracji - IOM (2015)³, Europejskiego Sondażu Społecznego 2014-2015 ${ }^{4}$ oraz trzy badania przeprowadzone w edukacji: badanie K.M. Błeszyńskiej Edukacja wobec wyzwań migracyjnych ${ }^{5}$ dotyczące dzieci obcokrajowców w polskich placówkach oświato-

2 Por. badania: A. Bergamaschi, Attitudes et représentations sociales. Les adolescents français et italiens face à la diversité, "Attitudes et représentations sociales», Revue européenne des sciences sociales [En ligne], 49-2 | 2011, mis en ligne le 01 janvier 2015, http://ress.revues. org/996 ; DOI : 10.4000/ress.996 [dostęp :1.12.2015]; J. Reeves, Secondary Teacher Attitudes toward Including English-Language Learners in Mainstream Classrooms, Learning and Teacher Education, 2006, Paper 116. http://digitalcommons.unl.edu/teachlearnfacpub/116 [dostęp: 15.01.16]; Sleeter, 2005; OECD, Creating Effective Teaching and Learning Environments: First Results from TALIS, 2009; OECD, Les élèves immigrés et l'école, Avancer sur le chemin de l'intégration, 2015. [dostęp: 15.01.16].

3 IPSOS dla IOM, 2015, Badanie na temat postaw wobec cudzoziemców w Polsce, http://udsc. gov.pl/postawy-wobec-cudzoziemcow-w-polsce/ [dostęp: 18.03.2016].

${ }^{4}$ K. Andrejuk, Postawy wobec imigrantów w świetle wyników Europejskiego Sondażu Społecznego 2014-2015. Polska na tle Europy, Zespół Studiów Europejskich, Working Paper 2/2015, Warszawa http://www.ifispan.pl/wp-content/uploads/2015/12/Postawy-wobec-imigrant\%C3\%B3w-w-\% C5\% 9Bwietle-wynik\%C3\% B3w-Europejskiego-Sonda \% C5\% BCu-Spo \% C5\%82ecznego2014-2015.-Polska-na-tle-Europy.pdf [dostęp: 20.03.2016].

${ }^{5}$ K.M. Błeszyńska, Edukacja wobec wyzwań migracyjnych, ORE, Warszawa 2010. www.ore. edu.pl [dostęp: 10.02.2016]. 
wych, badanie postaw młodzieży Młodzież, imigranci, tolerancja. Raport z badań terenowych w szkotach ${ }^{6}$ oraz badania systemu nauczania dzieci cudzoziemskich języka polskiego jako drugiego/obcego w szkołach w Polsce, zrealizowane w 2014 roku przez Fundację na rzecz Różnorodności Społecznej.

Jak wynika z badań przeprowadzonych na zlecenie Międzynarodowej Organizacji ds. Migracji (IOM), w czerwcu 2015 roku nastawienie Polaków wobec imigrantów było zdecydowanie bardziej pozytywne wśród osób, które wcześniej miały kontakt z cudzoziemcami na gruncie zawodowym czy prywatnym. Badani „wyrażali największą gotowość do akceptacji cudzoziemców jako kolegów z pracy i sąsiadów, a najmniejszą do ich akceptacji jako członków rodziny" ${ }^{\prime \prime}$. Najwyższą akceptację wyrażano wobec cudzoziemców postrzeganych jako bliskich kulturowo.

Interesujący obraz polskiego społeczeństwa wobec imigrantów jawi się w raporcie Katarzyny Andriejuk, opracowanym na podstawie Europejskiego Sondażu Społecznego 2014-2015 . Z badania tego wynika, że pomimo że Polska ma niski wskaźnik MIPEX (Migrant Integration Policy Index), oznaczający, że państwo nie traktuje priorytetowo polityki integracyjnej, to znajdujemy się wśród państw europejskich średnio przychylnych imigrantom. Badani podkreślali, że państwo polskie powinno przyjmować i zezwalać na zamieszkanie wyłącznie tym cudzoziemcom, którzy znają język polski i są gotowi przejąć styl życia utrwalony w naszym kraju. Czynniki ułatwiające integrację w sferze ekonomicznej, jak na przykład posiadanie kwalifikacji brakujących w Polsce, czy wykształcenie, wskazywano jako mające mniejsze znaczenie. K. Andriejuk podkreślając, że obydwie edycje ESS (z 2002 oraz 2015 r.) przedstawiły stabilne pozytywne postawy Polaków wobec uchodźstwa, wskazuje jednak na niepokojące zjawisko obserwowane w obecnych sondażach prowadzonych przez Centrum Badania Opinii Społecznej, gdzie

medialna eksploatacja zagadnienia uchodźstwa z państw pozaeuropejskich, jak również debaty polityczne dotyczące kwestii uchodźstwa miały wpływ na radykalizację poglądów oraz polaryzację opinii. Zmalała liczba osób opowiadających się za przyjmowaniem uchodźców (o 20 punktów procentowych). Wzrosła liczba respondentów deklarujących, że państwo nie powinno przyjmować imigrantów politycznych $^{10}$.

${ }^{6}$ J. Konieczna, E. Świdrowska, Młodzież, imigranci, tolerancja. Raport z badań terenowych w szkołach, Towarzystwo Demokratyczne Wschód, 2008. http://tdw.org.pl/galeria/publikacje/ mlodziez\%20imigranci\%20tolerancja/raport\%20o\%20szkolach\%20tdw.pdf [dostęp: 1.03.2016].

7 K. Kubin, E. Pogorzała, Raport z badania systemu nauczania dzieci cudzoziemskich języka polskiego jako drugiego/obcego w szkołach w Polsce, Warszawa 2014 http://ffrs.org.pl/biblioteka/ raporty/ [dostęp: 22.02.2016].

${ }^{8}$ Ipsos dla IOM, 2015. Badanie na temat postaw wobec cudzoziemców w Polsce.

${ }^{9}$ K. Andriejuk, Postawy wobec imigrantów w świetle wyników Europejskiego Sondażu Społecznego.

${ }^{10}$ Tamże. 
W 2008 roku badania postaw młodzieży wobec imigrantów prowadziły Joanna Konieczna i Ewa Świdrowska ${ }^{11}$. Z badania tego Młodzież, imigranci, tolerancja. Raport $z$ badań terenowych $w$ szkołach, zrealizowanego na zlecenie Towarzystwa Demokratycznego Wschód, wynika, że w szkołach wśród personelu pomocniczego dominowała neutralność, nierzadki był też dystans wobec cudzoziemców. Autorki raportu podkreślają, że najczęściej stosowana jest strategia ignorowania, ponieważ uczniowie z doświadczeniem migracji są nieliczni, to „jeśli nie sprawiają kłopotów wychowawczych - można ich praktycznie nie zauważać"12. Wynika ona również i z tego, że wiele szkół nie wie, jak postępować z uczniami z doświadczeniem migracji.

Ostatnie prezentowane badanie, przeprowadzone na zlecenie Ośrodka Rozwoju Edukacji przez Krystynę M. Błeszyńską, jest ważne i szerokie. W 2010 roku Autorka przebadała 134 nauczycieli, 194 dyrektorów szkół i 47 pedagogów szkolnych w celu poznania ich postaw wobec uczniów cudzoziemskich, a także oceny stopnia ich przygotowania do pracy z dziećmi z doświadczeniem migracji. K.M. Błeszyńska przyjęła następujące perspektywy badawcze problemu: perspektywę dyrektora szkoły, perspektywę nauczyciela i perspektywę pedagoga szkolnego. Większość badanych dyrektorów uznała, że obecność uczniów - obcokrajowców na terenie podległych im placówek stanowi wyzwanie, jednak co zaskakujące, jednocześnie prawie połowa badanych dyrektorów nie dostrzegała istnienia jakiejkolwiek specyfiki wynikającej z odmienności pochodzenia powierzonych ich placówce cudzoziemskich uczniów. Dyrektorzy w większości nie czuli się właściwie przygotowani do zarządzania placówkami kształcącymi uczniów o statusie uchodźczym lub imigranckim. Tylko 5\% z nich uważało, że ma wystarczające kompetencje $\mathrm{w}$ tym zakresie. Jedna czwarta respondentów deklarowała całkowity brak znajomości rozporządzeń, uregulowań prawnych i programów dotyczących kształcenia uczniów obcokrajowców w polskich szkołach.

Wśród nauczycieli niepokoił fakt, że aż 40\% nie uświadamiała sobie specyfiki pracy z tą grupą uczniów, ani nie widziała ich specjalnych potrzeb edukacyjnych. Większość ankietowanych nauczycieli wyraziła przekonanie o braku potrzeby dokonywania adaptacji sposobu ewaluacji ucznia do jego specyfiki kulturowej i językowej. Można powiedzieć, że obecność dzieci cudzoziemców w prowadzonej klasie wzbudzała ambiwalentne uczucia i niejednoznaczne postawy. Badaczka zauważyła, że praca z dziećmi cudzoziemskimi wywołuje u nauczycieli stres i poczucie przeciążenia. Zaskakujące w badaniu było, że około 90\% nauczycieli odczuwało, że są nieprzygotowani lub niewystarczająco przygotowani do pracy z uczniami-obcokrajowcami,

\footnotetext{
${ }^{11}$ J. Konieczna, E. Świdrowska, Młodzież, imigranci, tolerancja.

12 Tamże.
} 
a jednocześnie deklarowali, że są zdecydowanie zadowoleni z posiadanych kompetencji i wysoko oceniali swoje umiejętności pracy z uczniami-obcokrajowcami. Ten brak spójności w werbalnych deklaracjach nauczycieli pozwala na postawienie hipotezy, że większość nauczycieli faktycznie nie jest dobrze przygotowana do pracy z dziećmi z doświadczeniem migracji. Wskazywali oni na wiele barier integracyjnych, które przypisywali uczniom migrantom (ograniczenia językowe, odmienność religijna, niechęć do integrowania się), uczniom polskim (stereotypy i uprzedzenia etniczne), czy władzom oświatowym. Najrzadziej jednak badani nauczyciele dopatrywali się barier w swoim postępowaniu lub własnych cechach osobowości.

\section{Wzajemne postrzeganie się przez migrantów i społeczeństwo przyjmujące}

Ponieważ w naszym badaniu pilotażowym uczniowie cudzoziemscy to mali Ukraińcy i Wietnamczycy, warto również wziąć pod uwagę wybrane badania nad tymi dwiema narodowymi grupami imigrantów. Ciekawe dla nas są między innymi, prowadzone od ponad 20 lat, coroczne badania CBOS-u nad sympatiami i niechęcią Polaków do różnych narodów ${ }^{13}$. Przez ponad dwudzieścia lat wzrosła sympatia do niemal wszystkich branych pod uwagę narodów, zwłaszcza do Niemców oraz interesujących nas tu Ukraińców. Stosunek Polaków do innych narodów uwarunkowany był, i jest, wieloma czynnikami, między innymi wspólną historią oraz bieżącymi wydarzeniami i relacjami polityczno-gospodarczymi, toteż można zaobserwować jego zmiany na przestrzeni lat w obydwie strony - tak większej sympatii, jak i większej niechęci (np. wobec Rosji po napaści na Ukrainę).

Ukraińcy na tle innych narodów cieszą się jakkolwiek nadal umiarkowaną, to jednak bardzo wyraźnie rosnącą sympatią Polaków; między rokiem 1993 a 2013 rejestrowano spadek niechęci z 65\% aż do 33\%, zaś deklarowana sympatia do Ukraińców od początku badań w 1993 roku rosła i utrzymuje się od roku 2008 na poziomie powyżej 30\% ${ }^{14}$. Odnośnie do Wietnamczyków, to od 1998 roku poziom niechęci do nich utrzymuje się na poziomie średnim, to jest około 30\%, zaś wynik z 2013 roku, czyli 32\% sytuuje się zatem na zupełnie podobnym poziomie, co niechęć wobec Ukraińców, Żydów (34\%), Palestyńczyków (33\%), czy Turków (35\%), jakkolwiek nadal znajduje się na po-

${ }^{13}$ CBOS, Komunikat z badań nr 113/2015: Zmiany nastawienia Polaków do innych narodów, opracował Rafał Boguszewski, http:/ / www.cbos.pl/SPISKOM.POL/2015/K_113_15.PDF, [dostęp: 11.05 2016].

${ }^{14}$ CBOS Komunikat z badań BS/12/2013, Warszawa luty 2013: Stosunek Polaków do innych narodów, opracowała Beata Roguska, http://www.cbos.pl/SPISKOM.POL/2013/K_012_13. PDF, [dostęp: 11.05.2016]. 
ziomie wyraźnie korzystniejszym niż wynik najbardziej nielubianych przez Polaków - Romów (w 2013 r. 52\%, choć i tu spadek niechęci jest duży - z 75\% w roku 1993), niż często utożsamiani z Romami Rumuni (41\%), czy Rosjanie (39\%). Badanie przez CBOS deklarowanej sympatii wobec Wietnamczyków wykazuje na przestrzeni lat 1998-2013 niewielki wzrost i nadal średnioniski poziom (z 20\% do 25\%, co należy analizować na tle danych dotyczących najbardziej obdarzanych sympatią narodów, jak: Czesi - 51\%, Słowacy - 48\%, Anglicy - 47\%, Włosi - 46\% oraz najmniej lubianych, jak: Romowie - 20\%, Rumuni - 21\%, Turcy i Palestyńczycy - po $24 \%$, Chińczycy - 27\%, Żydzi $28 \%)^{15}$. Te dość ogólne dane, jako że dotyczą tylko prostych deklaracji badanych Polaków, pozwalają na oszacowanie hipotetycznych postaw wobec uczniów z Ukrainy i Wietnamu ze strony interesujących nas tutaj polskich uczestników systemu edukacyjnego. Powinny one być zatem bardziej pozytywne wobec Ukraińców niż Wietnamczyków, pozostając w obydwu przypadkach w „dolnej strefie stanów średnich”.

Spośród bogatej literatury przedmiotu w dziedzinie badań tak nad diasporą ukraińską, jak i wietnamską w Polsce, wybieramy jako szczególnie użyteczne dla tematu, czyli dla nakreślenia zarysów kontekstu dla edukacji dzieci ukraińskich i dzieci wietnamskich w polskiej szkole, dwa niedawne badania: G. Szymańskiej-Matusiewicz ${ }^{16}$ oraz R. Stefańskiej i M. Szuleckiej ${ }^{17}$.

Ukraińcy są najliczniejszą grupą migrantów w Polsce ${ }^{18}$, liczoną w setkach tysięcy osób, zaś Wietnamczycy - najliczniejszą nieeuropejską diasporą, stanowiącą około 25 000-30 000, według K. Wysieńskiej (2012)19 i G. Szymańskiej-Matusiewicz (2014) ${ }^{20}$. O swych kulturach, zwyczajach i historii Polacy oraz Ukraińcy wiedzą relatywnie bardzo dużo, zważywszy że znaczna część imigrantów z obywatelstwem ukraińskim ma w swojej rodzinie pochodzenia Polaków i ta część jest dwu- lub trójjęzyczna (ukraiński, polski, rosyjski) oraz że korzenie religijne obu kultur narodowych są chrześcijańskie. Również bezpośrednie sąsiedztwo Polski i Ukrainy, zwolnienie z wiz dla podró-

15 Tamże.

16 G. Szymańska-Matusiewicz, The Two Tet Festivals: Transnational Connections and Internal Diversity of the Vietnamese Community in Poland, "Central and Eastern European Migration Review", 2015(1), http://www.ceemr.uw.edu.pl/vol-4-no-1-june-2015/articles/two-t-t-festivals-transnational-connections-and-internal-diversity [dostęp: 10.05.2016].

17 R. Stefańska, M. Szulecka, Bezpieczny status prawny jako determinanta awansu ekonomiczno-zawodowego odmiennych grup imigrantów w Polsce, Central and Eastern European Migration Review, 2013, nr 1, s. 91-115, http:/ / www.ceemr.uw.edu.pl/vol-2-no-1-june-2013/articles/bezpieczny-status-prawny-jako-determinanta-awansu-ekonomiczno [dostęp: 8.05. 2016].

18 Tamże.

${ }^{19}$ K. Wysieńska (red.), Sprzedawać, gotować, budować? Plany i strategie Chińczyków i Wietnamczyków w Polsce, Warszawa 2012.

20 G. Szymańska-Matusiewicz, Vietnamese from Eastern Europe as a Transnational Migrant Community, [w:] The Age of Asian Migration: Continuity, Diversity, and Susceptibility, Volume I, red. Y.W. Chan, D. Haines, J. Lee, London 2014, s. 192-212. 
żujących na Ukrainę Polaków, rozwinięte relacje gospodarcze, wielka liczba przyjeżdżających do Polski na dłużej lub krócej Ukraińców (rozumiemy przez Ukraińców - obywateli ukraińskich), czyli jednym słowem - olbrzymia od powstania państwa ukraińskiego w 1991 roku - liczba kontaktów między obydwoma narodami rysuje tło dla edukacji dzieci ukraińskich jako bardzo bliskie kulturowo.

Jak podkreślają R. Stefańska i M. Szulecka,

te grupy imigranckie wyraźnie różnią się od siebie pod względem funkcjonowania w polskiej gospodarce. Nie bez znaczenia dla ich adaptacji ekonomicznej jest to, że Ukraińcy są Polakom bliżsi w sensie kulturowym i geograficznym niż Wietnamczycy, którzy na dodatek odróżniają się od Polaków wyglądem fizycznym (są tzw. migrantami widocznymi). Ukraińcy, w przeciwieństwie do Wietnamczyków, nie mają też tendencji do koncentracji w zakresie miejsc pracy czy zamieszkania, co również wpływa na ich możliwości adaptacji ekonomicznej, w tym pracy w środowisku Polaków ${ }^{21}$.

Ukraińcy i Wietnamczycy w Polsce różnią się też najczęściej pod względem statusu prawnego: wielu Wietnamczyków ma status na tyle nieuregulowany, że stale są zagrożeni deportacją, karami finansowymi, szantażem $\mathrm{i}$ temu podobnymi, czyli całkowitym zrujnowaniem budowanego w Polsce nowego etapu życia. Problem ten nie dotyka $\mathrm{w}$ żadnej porównywalnej mierze Ukraińców, choć wielu z nich musi sobie radzić z nie w pełni satysfakcjonującym statusem prawnym. Warto wspomnieć tutaj, że pomocna dla nich, istniejąca od 2010 roku, jest Karta Polaka, wydatnie ułatwiająca życie $\mathrm{w}$ Polsce cudzoziemcom polskiego pochodzenia przybywającym z krajów zza wschodnich granic.

Wietnamczycy dla przeciętnego Polaka stanowią terra incognito. Nawet osoby zajmujące się integracją cudzoziemców najwyraźniej niekoniecznie korzystają z istniejących opracowań naukowych zawierających stosowną wiedzę i potrafią wykazać podstawowe braki informacji o członkach tej diaspory. Ciekawy przykład podaje G. Szymańska-Matusiewicz (2015)22. Otóż, w 2008 roku prodemokratyczni aktywiści w Warszawie zorganizowali wystawę fotografii w celu ukazania życia Wietnamczyków w Polsce, jednak zatytułowali ją “Warsaw's Little Saigon" - mimo że wietnamska diaspora w Polsce wcale nie czuje się związana (jak to jest $\mathrm{w}$ przypadku diaspory $\mathrm{w}$ USA) $\mathrm{z}$ dawną niekomunistyczną Republiką Wietnamu, gdyż Wietnamczycy w Polsce pochodzą z Wietnamu Północnego; podobne faux-pas dotyczyło barw flagi narodowej i doboru politycznych w treści filmów; jednym słowem nieznajomość ludzi - Wietnamczyków „polskich” ukazała się w pełni i czyniła wydarzenie tego typu interesującym nie dla nich, a dla warszawiaków, co pokazała frekwencja.

${ }^{21}$ R. Stefańska, M. Szulecka, Bezpieczny status prawny jako determinanta awansu, s. 93.

${ }^{22}$ G. Szymańska-Matusiewicz, The Two Tet Festivals. 
Diaspora wietnamska w Polsce jest wysoce wewnętrznie zorganizowana, czego dowodzi istnienie licznych wietnamskich organizacji migranckich ${ }^{23}$. Owa wspólnota jest wewnętrznie zróżnicowana pod względem rozmaitych czynników, jak choćby czas pobytu w Polsce, rodzaj pracy, status prawny. Biorąc pod uwagę problemy komunikacji językowej między tymi imigrantami a Polakami, nieporównanie większe niż w przypadku słowiańskiego języka ukraińskiego, staje się jasne, iż od polskich nauczycieli nie można się spodziewać - bez wcześniejszych szkoleń - nawet podstawowej wiedzy o kulturowej tożsamości ich uczniów - małych Wietnamczyków, natomiast można oczekiwać sporej wiedzy w tym zakresie co do uczniów - Ukraińców.

Co jednak stanowi, na podstawie cytowanej literatury, o podobieństwie sytuacji w Polsce tych dwu odmiennych kulturowo diaspor, a zarazem jest istotne dla naszych badań, to:

- niezależnie od statusu prawnego wszyscy, nawet imigranci nielegalni, mają prawo by ich dzieci uczęszczały do szkoły w Polsce ${ }^{24}$;

- motywacja do pracy w Polsce w obu diasporach jest wysoka i owocuje wysoką aktywnością zawodową, nawet kiedy status prawny jest niekorzystny, jak konkludują swe badania nad Wietnamczykami i Ukraińcami w Polsce R. Stefańska i M. Szulecka:

Awans prawny nie miał wyraźnego wpływu na aktywność ekonomiczno-zawodową imigrantów, rozumianą tu jako posiadanie pracy, ponieważ większość badanych imigrantów - niezależnie od statusu prawnego i pochodzenia etnicznego - była aktywna zarobkowo ${ }^{25}$.

Zatem, uczniowie cudzoziemscy, którzy odgrywają rolę w naszym badaniu, mają najprawdopodobniej - tak można zakładać na podstawie wyżej wspomnianych tutaj badan - pracujących, a nie bezrobotnych rodziców, co ma duże znaczenie dla ich postaw edukacyjnych.

\section{Badania osobowości - zarys problematyki}

Osobowość w psychologii rozumiana jest najczęściej jako zespół względnie stałych predyspozycji do zachowania. Zatem, w tym miejscu autorki pragną przedstawić pojęcie osobowości w zakresie niezbędnym dla niniejszej pracy badawczej. Spośród wielu możliwych, do oceny osobowości nauczycieli wybrano Pięcioczynnikowy Model Osobowości. Jest to jeden z dominują-

${ }^{23}$ T. Halik, Migrancka społeczność Wietnamczyków w Polsce w świetle polityki państwa i ocen społecznych, Poznań 2006; K. Wysieńska (red.) Sprzedawać, gotować, budować?

${ }^{24}$ R. Stefańska, M. Szulecka, Bezpieczny status prawny jako determinanta awansu, s. 94.

${ }^{25}$ Tamże, s. 111. 
cych modeli we współczesnej psychologii osobowości, a zarazem - co istotne dla pracy interdyscyplinarnej, łączącej perspektywę psychologiczną i glottodydaktyczną - jeden $\mathrm{z}$ najpopularniejszych modeli w badaniach stosowanych dotyczących osobowości ludzi zdrowych, na przykład w procedurach rekrutacji kadr i programowania kariery zawodowej.

Już klasycy psychologii osobowości, jak Cattell, Allport, czy Odbert, szukali poprzez swoje badania zamkniętej liczby czynników składających się na strukturę osobowości i co za tym idzie, mogących stanowić punkt wyjścia do budowy testów dla potrzeb praktyki. U podłoża Pięcioczynnikowego Modelu Osobowości leżą liczne badania leksykalne, psychometryczne oraz badania oparte na swobodnych opisach i samoopisach. Owe opisy, złożone z wielu określeń, poddawano następnie analizie czynnikowej, która pozwala wyodrębnić mniejszą liczbę czynników, co często doprowadzało właśnie do liczby pięciu. Jako pierwszy właśnie pięć czynników wyodrębnił Warren Norman (1967). Z kolei Lewis Goldberg, uczeń Normana, nawiązał do tej koncepcji na fali wzmagającego się w latach 80. XX wieku ponownego zainteresowania PMO. Jest on autorem określenia „Wielka Piątka” (Big Five $)^{26}$. Należy zaznaczyć, że liczni badacze wyodrębniający poprzez analizę czynnikową liczbę pięciu czynników nie zawsze wyznaczali te same czynniki.

L. Goldberg przyjął tak zwaną hipotezę leksykalną, która głosi, że: po pierwsze - różnice indywidualne między ludźmi znajdują swój wyraz w języku, po drugie - im większe znaczenie ma określona różnica, tym częściej ludzie zwracają na nią uwagę, tym częściej o niej rozmawiają, aż w końcu wynajdują opisujący ją termin. Autor ten (jak również inni badacze PMO, w tym w Polsce Paweł Szarota (1995)) postępował następująco: wybierał ze słownika wszystkie określenia - przymiotniki - opisujące zachowania człowieka, następnie grupował je w wiązki synonimów, które z kolei poddawał technikom analizy czynnikowej. W ten sposób otrzymał pięć czynników.

Paul T. Costa i Robert R. McCrae, którzy są autorami użytego w naszym badaniu testu do badania osobowości, mierzącego 5 czynników osobowości NEOAC, wykorzystali w jego tworzeniu zarówno klasyczny 16-czynnikowy kwestionariusz Cattella, jak 2-czynnikowy Eysencka (wymiary, neurotyczność i ekstrawersja). Uwzględnili wymiar dotyczący intelektu, kultury i wyobraźni, nadając mu nazwę "Otwartość na doświadczenie”, a także wynikające z badań leksykalnych czynniki: ugodowość i sumienność. Nazwa NEOAC pochodzi od pierwszych liter angielskich nazw czynników: Neuroticism, Extraversion, Openness to experience, Agreeableness i Conscientiousness.

${ }^{26}$ L. Goldberg, Language and Individual Differences: The Search for Universals in Personality Lexicons [w:] Review of Personality and Social Psychology, red. L. Wheeler, Beverly Hills, CA:1981. 
Autorzy testu P.T. Costa i R.R. McCrae definiują pojęcie osobowości wyłącznie operacyjnie: „osobowość to struktura najbardziej podstawowych wymiarów, wpływających na cechy identyfikowane zarówno w naturalnych językach, jak i kwestionariuszach psychologicznych".

\section{Metodologia badań}

\section{Cel badania}

Badania prowadzone $\mathrm{w}$ takich krajach, jak USA, Francja, czy Włochy o dużej praktyce $\mathrm{w}$ uczeniu dzieci z doświadczeniem migracji pokazują, że sukcesy szkolne dzieci migrantów zależą w dużej mierze od postaw uczących ich nauczycieli i zarządzających placówką dyrektorów. Kierujący polskimi placówkami szkolnymi coraz częściej stoją przed dylematami: do jakich klas przydzielić uczniów z doświadczeniem migracji, którym nauczycielom powierzyć opiekę nad tymi uczniami o specjalnych potrzebach edukacyjnych. Badania amerykańskie prowadzone przez badaczy z The University of North Carolina, na zlecenie EPIC (Education Policy Initiative at Carolina) ${ }^{27}$ obrazują także, iż niektóre cechy osobowości są pożądane u nauczycieli pracujących z tymi uczniami. Biorąc pod uwagę fakt, że temat skutecznej edukacji inkluzyjnej jest aktualny w kontekście zwiększającej się liczby dzieci z doświadczeniem migracji, podjęłyśmy decyzję o zrealizowaniu badania w małopolskich szkołach, które mają na celu zbadanie, jakie czynniki, w tym i sama osobowość, warunkują postawy (negatywne i pozytywne) wobec uczniów $\mathrm{z}$ doświadczeniem migracji. Badamy, $\mathrm{w}$ jakim stopniu doświadczenie pracy z uczniem cudzoziemskim wpływa na postawy nauczycieli wobec tych dzieci. W realizowanym projekcie badawczym pragniemy ustalić, czy istnieją cechy osobowości warunkujące postawy (pozytywne, jak i negatywne) wobec uczniów migrantów oraz czy istnieje korelacja między ich postawami i deklarowanymi zachowaniami a tymi cechami.

\section{Metoda i narzędzia badawcze}

Planowany projekt badawczy będzie zrealizowany w dwóch etapach: pilotażowym i zasadniczym. Niniejsze badanie pilotażowe stanowiło pierwszy etap badań postaw nauczycieli wobec dzieci migrantów i badania ich osobowości. Jego celem było także sprawdzenie wybranych do badania narzędzi

27 K.C. Bastion i in., Do personality Traits Impact Beginning Teacher Performance and Persistence? 2015, http://www.wcu.edu/WebFiles/PDFs/CEAP_PersonalityTraits_2015.pdf [dostęp: 2.01.2016]. 


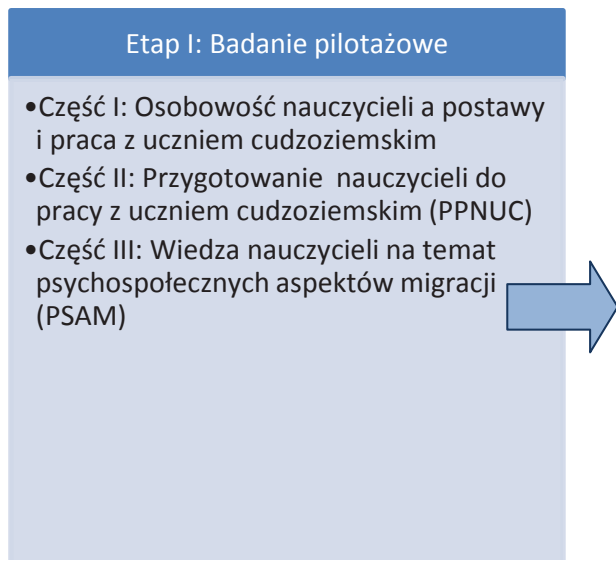

Etap II: Badanie zasadnicze
•Część I: Osobowość nauczycieli a praca z
uczniem cudzoziemskim
•Część II: Przygotowanie nauczycieli do
pracy z uczniem cudzoziemskim (PPNUC)
•Część III: Wiedza nauczycieli na temat
psychospołecznych aspektów migracji
(PSAM)
•Część IV: Postawy nauczycieli i
przygotowanie wobec uczniów
cudzoziemskich - wywiady pogłębione
•Część V: Postawy dyrektorów szkoły
wobec zagadnień związanych z edukacją
dzieci migrantów - wywiady pogłębione

Ryc. 1. Schemat badania

badawczych oraz zaobserwowanie tendencji w badanej grupie. Zaplanowano je jako badanie ilościowe.

Badanie zasadnicze zaprojektowano jako badanie triangulacyjne, w którym badani będą nauczyciele oraz dyrektorzy za pomocą kwestionariuszy, testów oraz wywiadów pogłębionych, a następnie zostanie dokonane porównanie i synteza wyników.

Część pierwszą badania pilotażowego dla potrzeb niniejszego artykułu będziemy odtąd nazywać badaniem.

\section{Opis technik i narzędzi badawczych}

W badaniu korzystano z dwóch technik badawczych: ankiety i testu. Użyto trzech narzędzi badawczych: dwóch opracowanych przez badaczki kwestionariuszy ankiet oraz ze standaryzowanego kwestionariusza testu osobowości NEO-FFI. W tekście niniejszego artykułu omówione zostaną tylko dwa z nich: PPNUC - kwestionariusz ankiety dotyczącej postaw i przygotowania nauczycieli do pracy z uczniem cudzoziemskim oraz NEO-FFI - test osobowości, jako że prezentowane wyniki badań dotyczą wyłącznie części pierwszej badania pilotażowego: osobowości nauczyciela oraz pracy i postaw nauczycieli wobec dzieci migrantów.

W metryczce badania zebrano ogólne informacje na temat badanych, jak: płeć, staż pracy, wykształcenie, informacje o doświadczeniu migracji własnej lub w rodzinie, a także informacje dotyczące znajomości języków obcych (wg skali ESOKJ - Europejskiego Systemu Opisu Ksztatcenia Językowego)

PPNUC - Kwestionariusz dotyczący postaw i przygotowania nauczycieli do pracy z uczniem cudzoziemskim. Dotyczy postaw nauczycieli wo- 
bec uczniów migrantów oraz przygotowania nauczycieli do pracy z uczniem cudzoziemskim. Zawiera 30 stwierdzeń, a odpowiedzi do wyboru zbudowane są na pięciostopniowej skali Likerta. Pierwsza część (stwierdzenia 1-23) adresowana jest do wszystkich nauczycieli, natomiast druga (stwierdzenia 24-30) została skierowana wyłącznie do nauczycieli uczących dzieci migrantów. Stwierdzenia w pierwszej części dotyczą postaw wobec edukacji dzieci z doświadczeniem migracji, znajomości elementów akwizycji języka obcego/drugiego oraz samooceny przygotowania do pracy z dzieckiem cudzoziemskim (przygotowanie zawodowe i doskonalenie warsztatu nauczyciela). Część druga dotyczy nauczycieli obecnie pracujących z dziećmi cudzoziemskimi. Ma na celu zebranie informacji na temat postaw nauczycieli oraz samooceny pracy z uczniem cudzoziemcem, czyli uczniem o specjalnych potrzebach edukacyjnych.

NEO-FFI - Test osobowości. Do zrealizowania badania osobowości wykorzystałyśmy test P.T. Costy i R.R McCrae w adaptacji P. Szczepaniaka, M. Śliwińskiej, J. Strelau i B. Zawadzkiego ${ }^{28}$.

P.T. Costa i R.R. McCrae skonstruowali kwestionariusz, w którym dokonywany opis następuje przez zdania ujmujące kontekst. Istnieje jego pełna wersja, złożona z 240 pozycji, zwana NEO-PI-R, oraz bardziej popularna i często stosowana w praktyce, w tym w zakresie HR wersja skrócona: NEO-FFI, składająca się z 60 pozycji, po 12 na wymiar (czynnik).

1. Neurotyczność jako wymiar osobowości odzwierciedla przystosowanie emocjonalne versus emocjonalne niezrównoważenie. Zatem, neurotyczność oznacza podatność na doświadczanie takich negatywnych emocji, jak strach, zmieszanie, niezadowolenie, gniew, poczucie winy oraz wrażliwość na stres psychologiczny. Ze względu na fakt, że emocje negatywne rzutują na adaptację jednostki do środowiska, osoby z wysoką neurotycznością są skłonne do irracjonalnych pomysłów, stosunkowo mało zdolne do kontrolowania swoich popędów oraz zmagania się ze stresem. Osoby z niską neurotycznością są natomiast emocjonalnie stabilne, spokojne, zrelaksowane, zdolne do zmagania się ze stresem, bez doświadczania obaw, napięć i rozdrażnienia.

2. Ekstrawersja jest wymiarem charakteryzującym jakość i liczbę interakcji społecznych oraz poziom aktywności, energii i zdolność do odczuwania pozytywnych emocji. Osoby ekstrawertywne są zatem nie tylko przyjacielskie i rozmowne, ale także skłonne do zabawy i poszukiwania stymulacji, jak również wykazują optymizm życiowy i pogodny nastrój. Osoby o niskim poziomie tego czynnika, czyli introwertywne, charakteryzuje raczej brak zachowań ekstrawertywnych, niż ich pełna odwrotność. Wykazują one zatem raczej rezerwę w kontaktach społecznych niż wrogość, brak optymizmu, któ-

${ }_{28}$ B.A. Zawadzki i in., Inwentarz Osobowości NEOFFI Costy i McCrae. Polska adaptacja. Podręcznik, Warszawa 1998. 
ry niekoniecznie musi oznaczać pesymizm, oraz preferencje do przebywania w samotności i nieśmiałość, co nie oznacza lęku społecznego: introwertykowi bowiem nie zależy na towarzystwie, ponieważ lubi być sam.

3. Otwartość na doświadczenie to wymiar opisujący tendencje jednostki do poszukiwania i pozytywnego wartościowania doświadczeń życiowych, tolerancję wobec nowości i ciekawość poznawczą. Osoby o wysokiej otwartości są ciekawe zjawisk zarówno świata zewnętrznego, jak wewnętrznego oraz mają życie bogatsze pod względem liczby doświadczeń i przeżyć. Osoby o niskiej otwartości są natomiast konwencjonalne w zachowaniu i konserwatywne w poglądach. Otwartość, najbardziej ze wszystkich czynników osobowości NEOAC, wiąże się z cechami intelektu. Związek ten dotyczy raczej zdolności do myślenia dywergencyjnego i kreatywności niż zdolności do myślenia konwergencyjnego i inteligencji akademickiej. P.T. Costa i R.R. McCrae uważają, że wielu bardzo inteligentnych ludzi nie jest otwartych na doświadczenie, a równocześnie wielu otwartych ludzi nie jest szczególnie sprawnych intelektualnie. Wartość dużej lub małej otwartości zależy w głównej mierze od wymagań środowiska i sytuacji. Na przykład, trudno pozytywnie wartościować dużą otwartość w zawodach, których przedstawiciele mają być ostoją prawa, niezłomnych zasad i praworządności (np. audytor, urzędnik skarbowy, czy policjant).

4. Ugodowość stanowi wymiar opisujący pozytywne versus negatywne nastawienie do innych ludzi, orientację interpersonalną przejawiającą się $\mathrm{w}$ altruizmie versus antagonizmie, doświadczanych $\mathrm{w}$ uczuciach, myślach i działaniu. Na poziomie poznawczym cecha ta przejawia się jako zaufanie do innych ludzi bądź brak zaufania, na poziomie emocjonalnym - jako wrażliwość lub obojętność na sprawy innych ludzi, zaś na poziomie behawioralnym - jako nastawienie kooperacyjne lub rywalizacyjne. Osoby o wysokiej ugodowości są zatem sympatyczne wobec innych, skłonne do udzielania im pomocy oraz sądzą, że inni ludzie mają podobne postawy. Natomiast, osoby mało ugodowe są egocentryczne i sceptyczne w opiniach na temat intencji innych ludzi i częściej nastawione rywalizacyjnie niż kooperacyjnie. Ugodowość jako cecha osobowości nie powinna być wartościowana w prosty sposób, gdyż z punktu widzenia zarządzania zasobami ludzkimi wartościowy może być każdy poziom cechy w zależności od roli przewidzianej dla jednostki w organizacji, środowiska, zadań. Wysokie stanowiska kierownicze wymagają osób o niższej ugodowości niż stanowiska wykonawców.

5. Sumienność to wymiar osobowości, który charakteryzuje stopień zorganizowania, wytrwałości i motywacji jednostki w działaniach zorientowanych na cel; innymi słowy - wymiar ten opisuje stosunek człowieka do pracy, wolę dążenia do osiągnięć, popularnie tak zwany "charakter". Osoby o wysokiej sumienności wykazują silną wolę, są zmotywowane do działania oraz wytrwałe w realizowaniu swoich celów. Są postrzegane jako skrupulatne, punk- 
tualne i rzetelne w pracy. Mają duże osiągnięcia akademickie i zawodowe, a także przekonanie o możliwości radzenia sobie w życiu oraz umiejętność samomotywowania się do ukończenia rozpoczętego zadania. Duże nasilenie tej cechy może jednak przejawiać się pracoholizmem, nadmierną skłonnością do utrzymywania porządku i uciążliwym perfekcjonizmem. Natomiast, osoby o niskiej sumienności odznaczają się mniejszym nasileniem wymienionych cech, a nie ich przeciwieństwem. Są mniej skrupulatne w przestrzeganiu zasad, mniej zmotywowane do osiągnięć, często wykazują hedonistyczne nastawienie do życia.

Co ważne, aby zaznaczyć, iż powyższe cechy charakteryzują osobowość normalną, zdrową, należy podkreślić, że mają one charakter ciągły, a nie biegunowy, czyli mają normalny rozkład w populacji. Jakkolwiek autorzy NEOAC podkreślają złożoność kwestii wartościowania cech, w percepcji ogółu ludzi korzystny wizerunek osoby oznacza najczęściej niską neurotyczność oraz wysoki ekstrawertyzm, otwartość na doświadczenie, ugodowość i sumienność.

Koncepcja NEOAC i zbudowane na jej podstawie narzędzie badawcze, jakim jest NEO-FFI wydają się autorkom szczególnie wartościowe dla potrzeb badań nad czynnikami kształtującymi postawy nauczycieli wobec uczniów z doświadczeniem migracji.

\section{Opis grupy badanej i reprezentatywność grupy}

W badaniu wzięło udział 40 nauczycieli, 38 kobiet (95\%) i 2 mężczyzn (5\%). Wszyscy są nauczycielami małopolskiej szkoły podstawowej. Te dysproporcje płci są bliskie rzeczywistemu podziałowi ze względu na płeć w populacji nauczycieli polskich i nie tylko polskich, zwłaszcza w szkołach podstawowych. Na podstawie danych GUS-u, 81\% wszystkich nauczycieli w Polsce stanowią kobiety. W szkołach podstawowych jest ich jeszcze więcej. W edukacji wczesnoszkolnej znakomitą większość nauczycieli stanowią kobiety, jedynie co setny nauczyciel to mężczyzna.

Raport o stanie edukacji z 2103 roku „Liczą się nauczyciele”29 pokazuje, że przeciętny polski nauczyciel ma 42 lata. W naszym badaniu respondenci to nauczyciele $\mathrm{w}$ większości w średnim wieku, $\mathrm{z}$ dość dużym stażem i doświadczeniem zawodowym. Największą grupę (55\%) stanowili nauczyciele pomiędzy 35. a 50. rokiem życia. 28\% badanych liczyło powyżej 50 lat. Grupę nauczycieli młodych reprezentowało 17\% grona pedagogicznego. Większość badanych $(67,5 \%)$ ma staż pracy powyżej 15 lat, a 12\% nauczycieli uczyło w szkole od 10-15 lat. 15\% badanych stanowili nauczyciele rozpoczynający

${ }^{29}$ M. Federowicz, M. Sitek, Licza się nauczyciele. Raport o stanie edukacji 2013, http://eduentuzjasci.pl/publikacje-ee-lista/raporty/150-raport-o-stanie-edukacji/1052-raport-o-stanie-edukacji-2013-licza-sie-nauczyciele.html [dostęp: 30.01.2016]. 
karierę zawodową o stażu sięgającym do 5 lat. Niewielką grupę (2,5\%) reprezentowali nauczyciele o 5-10-letnim stażu.

Prowadziliśmy także badania odnośnie wykształcenia nauczycieli oraz ich stopnia awansu zawodowego. Pokazują one, że chociaż istnieje wiele czynników decydujących o efektywności nauczyciela, to wykształcenie może być jednym z predykatorów skutecznego nauczania. Zdecydowana większość nauczycieli (97,5\%) ma wykształcenie wyższe. Tylko 2,5\% nauczycieli legitymuje się dyplomem licencjata. Duża grupa nauczycieli osiągnęła wysoki stopień awansu zawodowego: $60 \%$ badanych stanowili nauczyciele dyplomowani, $10 \%$ grona pedagogicznego - nauczyciele stażyści, 10\% - nauczyciele kontraktowi, a 20\% - nauczyciele mianowani. Odzwierciedla to także wyniki bliskie średnim wynikom krajowym. W Polsce, jak piszą autorzy Raportu o stanie edukacji 2013, 51\% nauczycieli osiągnęło stopień nauczyciela dyplomowanego, 28\% - nauczyciela mianowanego, $17 \%$ - nauczyciela kontraktowego. Jak piszą wspomniani autorzy, „mamy do czynienia $\mathrm{z}$ «odwróconą piramidą» awansu zawodowego - ponad połowa nauczycieli ma najwyższy stopień nauczyciela zawodowego". Pokazuje to, że stosunkowo bardzo szybko można w obecnym systemie dotrzeć na szczyt kariery zawodowej.

W kontekście tematu niniejszych badań interesowało nas także, czy sami nauczyciele mieli osobiste doświadczenie migracji oraz czy w ich rodzinie były osoby z doświadczeniem migracji. Okazało się, że 15\% badanych mieszkało za granicą od jednego roku do trzech lat, a ponadto aż $65 \%$ badanych miało wśród członków rodziny osoby przebywające na emigracji, przy czym długość pobytu waha się od kilku miesięcy do kilkunastu lat. Ten wynik zasługuje na dalsze pogłębione analizy, lecz nie wydaje się autorkom zaskakujący, jako że Polska jest krajem intensywnych migracji zagranicznych. Emigracja stanowi zjawisko społeczno-ekonomiczne, nierozerwalnie związane z historią naszego kraju. Wielkość tak zwanych zasobów imigracyjnych Polaków w innych krajach jest znacząca. Główny Urząd Statystyczny szacuje, że pod koniec 2014 roku poza granicami państwa polskiego przebywało czasowo blisko 2 miliony 320 tysięcy mieszkańców naszego kraju ${ }^{30}$. W badanej grupie bezpośrednie, a zwłaszcza pośrednie doświadczenie migracji jest dość powszechne.

Kolejne pytanie skierowane do nauczycieli dotyczyło znajomości języków obcych. 95\% nauczycieli oświadczyło, że potrafi komunikować się w języku obcym, przy czym badani najczęściej deklarowali znajomość języka na poziomie podstawowym (A). Niewielu nauczycieli znało język obcy na poziomie

${ }^{30}$ GUS, 2015. Informacja o rozmiarach i kierunkach czasowej emigracji z Polski w latach 2004 - 2014. http://stat.gov.pl/download/gfx/portalinformacyjny/pl/defaultaktualnosci/5471/11/1/1/ szacunek_emigracji_z_polski_w_latach_2004-2014.pdf 
B, a znikoma liczba na poziomie C. Najpopularniejszym, znanym językiem wśród badanych był język angielski, na drugim miejscu wymieniono język niemiecki, a następnie rosyjski. Najmniej popularne języki to francuski, hiszpański i włoski. Znajomość języka rosyjskiego wśród badanych wynika prawdopodobnie $\mathrm{z}$ faktu, że $\mathrm{w}$ gronie pedagogicznym dość dużą grupę stanowią nauczyciele, którzy edukację szkolną odbywali w czasach, kiedy wszyscy uczniowie uczyli się języka rosyjskiego.

\section{Przebieg badań}

Badanie zostało przeprowadzone $\mathrm{w}$ jednej z krakowskich szkół podstawowych. Jest to duża szkoła publiczna w dzielnicy, w której mieszka stosunkowo wielu cudzoziemców, głównie Wietnamczyków. Mieści się w niej duże targowisko, tak zwana Tandeta, gdzie znajdują oni zatrudnienie. Szkoła od lat przyjmuje dzieci migrantów. Obecnie, w roku szkolnym 2015/2016, jak podaje dyrektor, w szkole uczy się szesnaścioro dzieci cudzoziemskich: piętnaścioro Wietnamczyków i jedno dziecko z Ukrainy. W szkole pracuje 60 nauczycieli, pedagogów i opiekunów. Niektórzy uczą w klasach, w których są dzieci z doświadczeniem migracji, natomiast inni takich uczniów ze specjalnymi potrzebami edukacyjnymi nie uczą.

Kwestionariusze wraz $\mathrm{z}$ testem osobowości zostały przekazane nauczycielom w odrębnych kopertach. Do ankiet i testu dołączono list wraz z informacją o badaniu. Nauczyciele zostali poinformowani, że badanie jest anonimowe, a jego wyniki posłużą tylko i wyłącznie do celów naukowych. Otrzymaliśmy zwrotnie 40 wypełnionych ankiet i testów w zaklejonych anonimowych kopertach. Wyniki zostały zakodowane i poddane analizie statystycznej. Poniżej przedstawiamy wybrane wyniki zrealizowanego badania.

\section{Wyniki badań}

\section{Cechy osobowości nauczycieli. Porównanie wyników nauczycieli uczących i nieuczących dzieci cudzoziemskie}

Badanie pilotażowe pokazało, że nauczyciele uczący dzieci cudzoziemskie cechuje większa ekstrawersja i korelacja ta jest wysoka, statystycznie istotna.

Rycina 2 przedstawia porównanie dwóch grup nauczycieli: uczących dzieci cudzoziemskie (NU) i nieuczących dzieci cudzoziemskie (NN) pod względem ich cech osobowości. 


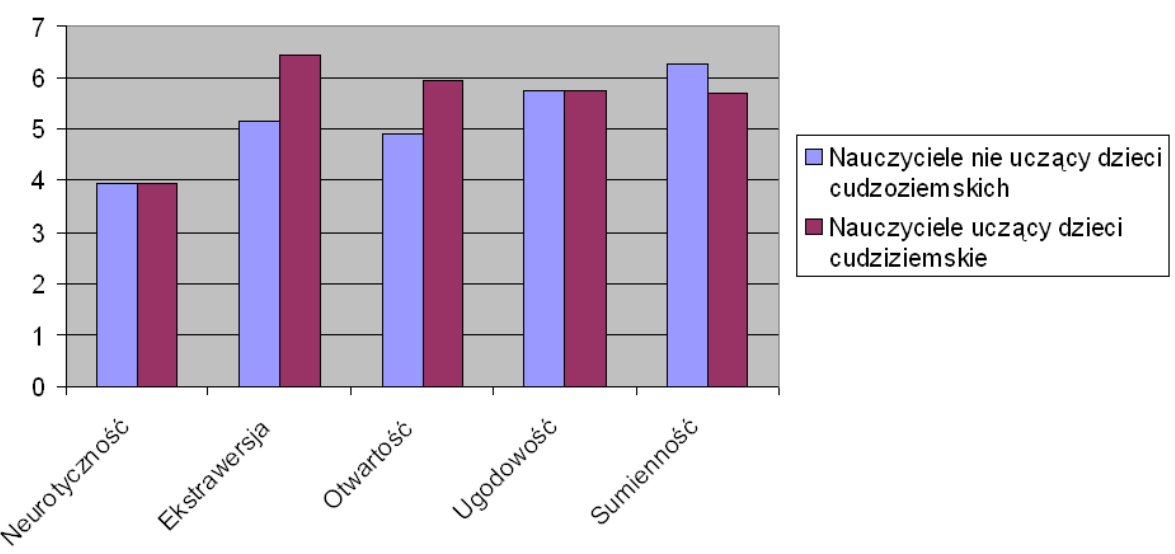

Ryc. 2. Osobowość nauczycieli uczących i nieuczących dzieci cudzoziemskie - średnie arytmetyczne z wyników jednostkowych przełożonych na steny

Na podstawie przeprowadzonych badań pilotażowych wskazano, że fakt podejmowania przez nauczycieli pracy z dziećmi cudzoziemskimi:

- nie jest skorelowany ze znajomością przez nich języków obcych $(p>, 05)$,

- nie jest skorelowany z ich doświadczeniami związanymi z migracją (pobyt za granicą nauczyciela lub osoby z rodziny) $(p>, 05)$,

- jest prawdopodobnie skorelowany $\mathrm{z}$ wiekiem nauczycieli - młodsi nauczyciele częściej pracują z dziećmi cudzoziemskimi (tendencja ,01 > p >,05).

W badaniu byliśmy zainteresowani także, czy istnieje zależność między cechami nauczycieli a uczestniczeniem i deklarowaną chęcią uczestnictwa w różnych formach doskonalenia zawodowego związanych z pracą z uczniem $\mathrm{z}$ doświadczeniem migracji.
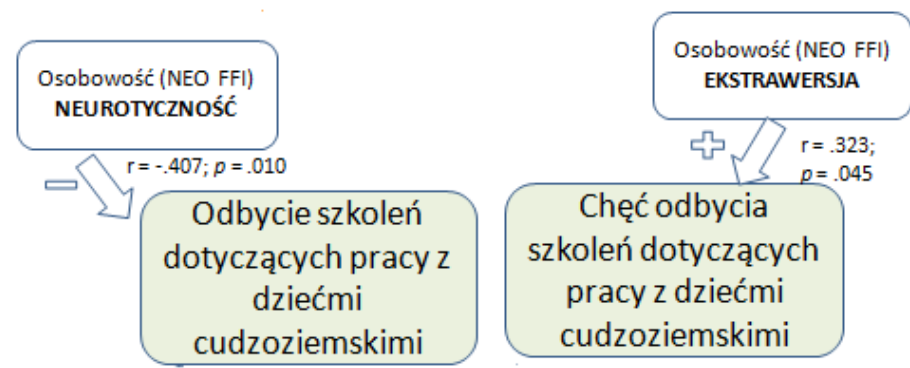

Ryc. 3. Cechy nauczycieli a uczestnictwo oraz deklaracja uczestnictwaw formach doskonalenia zawodowego nauczycieli dla potrzeb pracy z uczniem 
Rycina 3 przedstawia korelacje pomiędzy cechami nauczycieli a faktem odbycia form doskonalenia zawodowego nauczycieli dla potrzeb pracy z uczniem cudzoziemskim i deklarowaną chęcią uczestniczenia w przyszłości $\mathrm{w}$ takich szkoleniach.

Przeprowadzone badania pilotażowe pozwoliły ukazać, że odbycie szkoleń dotyczących pracy z dziećmi cudzoziemskimi jest ujemnie skorelowane $\mathrm{z}$ cechą osobowości „neurotyczność” $(\mathrm{r}=-, 407 ; p=, 010)$.

Na podstawie przeprowadzonej analizy wykazano istniejącą korelację pomiędzy poziomem ekstrawersji nauczycieli a ich zainteresowaniem podjęcia szkoleń dotyczących sposobów pracy z uczniami z doświadczeniem migracji.

Zwrócono uwagę, że deklarowana przez nauczycieli chęć odbycia szkoleń dotyczących pracy z dziećmi cudzoziemskimi jest ujemnie skorelowana ze stażem pracy $(\mathrm{r}=-, 385 ; p=, 015)$.

\section{Wnioski z badania}

1. Przeprowadzone badania pozwoliły na stwierdzenie, że osobowość nauczycieli pracujących z uczniami (NU) różni się od osobowości nauczycieli niepracujących z uczniami cudzoziemskimi (NN) pod względem jednego z pięciu wymiarów osobowości, jakim jest ekstrawersja. NU cechuje wyższa ekstrawersja, natomiast NN - niższa. Wynik nie zaskakuje, ponieważ dla osobowości ekstrawertycznej właściwa jest wyższa jakość i liczba interakcji społecznych oraz poszukiwanie stymulacji, czyli w tym przypadku wyższe predyspozycje do pracy z dzieckiem o całkiem nowych dla nauczyciela cechach i potrzebach edukacyjnych.

Nie wiadomo natomiast, dlaczego tak się stało, iż właśnie ci a nie inni nauczyciele zaczęli pracować z tymi dziećmi. Czy jest tak, że sami nauczyciele o osobowości bardziej ekstrawertycznej wyrażają gotowość do przyjęcia dzieci migrantów do swojej klasy? Czy też o zaistnieniu związku „nauczyciel - dziecko" decyduje dyrektor szkoły, który znając swoich pracowników, wie do kogo lepiej wysłać dziecko wymagające większej pomocy i specjalnej troski? A może zachodzi i jedno, i drugie zjawisko? Nie wiemy także, na ile owo trafianie dzieci migrantów do nauczycieli ekstrawertycznych jest wynikiem świadomych czy nieświadomych działań nauczycieli lub/i dyrektora szkoły.

2. W przypadku naszego badania nie wystąpiła zależność pomiędzy cechą osobowości nauczyciela określaną jako „sumienność” a faktem uczenia dzieci cudzoziemskich. Tymczasem, spodziewałyśmy się wystąpienia tej zależności, wychodząc z założenia, iż praca z dzieckiem-migrantem z zasady wymaga więcej wytrwałości, motywacji, cierpliwości, a więc większej rzetelności 
w pracy niż przeciętnie. Również niedawne badania dotyczące nauczycieli amerykańskich z użyciem NEO-FFI, przeprowadzone w 2015 roku przez zespół K.C. Bastian, D.M. McCord, J.T Marks i D. Carpenter (University of North California) wykazały, że skuteczność działania nauczyciela w procesie uczenia uczniów z doświadczeniem migracji i uczniów ze środowisk o niskim statusie społeczno-ekonomicznym zależy od jego sumienności.

Czy zatem może być tak, że poziom sumienności w całej grupie badanych nauczycieli jest na tyle wysoki (średnia, wyliczona z wyników jednostkowych przeliczonych na steny, dla całej grupy wynosi 5,98), iż pracują oni rzetelnie niezależnie od tego kogo uczą? Należy przypuszczenie to sprawdzić w dalszym badaniu na większej grupie.

3. W przedstawionych przez nas wynikach badań może też dziwić, że fakt uczenia dzieci cudzoziemskich nie jest znacząco skorelowany ze znajomością przez nauczycieli języków obcych. Wszak znajomość języka, którym włada uczeń jest z pewnością bardzo przydatna, szczególnie na początku, kiedy komunikacja $w$ języku edukacji szkolnej jest ograniczona. Jak można zatem rozumieć ten wynik? Otóż, w naszej badanej grupie nie ma nauczycieli, którym język macierzysty ich ucznia-cudzoziemca byłby znany. Mamy tu bowiem dwie grupy uczniów: Wietnamczyków i Ukraińców. W Polsce język wietnamski stanowi język egzotyczny. Jednakże, nauczyciele nie znają również języka ukraińskiego ani rosyjskiego, który byłby pomocny w komunikacji z Ukraińcami. Badani przez nas nauczyciele mają mniej niż 37 lat i w większości nie uczyli się już języka rosyjskiego, który po 1989 roku właśnie dla ich pokoleń przestał być przedmiotem obowiązkowym.

4. Zaskakujący jest też wynik badania korelacji pomiędzy doświadczeniem związanym z migracją a uczeniem lub nieuczeniem dzieci cudzoziemskich. Pokazuje on, że takiej współzależności na poziomie znaczącym statystycznie nie ma. Dziwi to, bo duży procent badanych posiada owo doświadczenie, czy to własne czy w bliskiej rodzinie, i wydawałoby się, że wiedza płynąca z takich doświadczeń powinna uprawdopodobniać lepsze radzenie sobie z zadaniem nauczania i wychowywania dzieci-migrantów.

Zakładamy więc przypuszczenie, że dobór uczniów do klas odbywa się spontanicznie i nieświadomie, tak ze strony nauczycieli jak dyrektorów, i dlatego pewne cechy osobowości (ekstrawersja) są istotniejsze niż doświadczenia migracji nauczyciela. Również ta hipoteza wymaga dalszych badań.

5. Interesujące są także wyniki niniejszego badania, dotyczące doskonalenia zawodowego nauczycieli. Pokazało ono, że istnieje ujemna korelacja między wiekiem nauczyciela a chęcią odbycia przezeń szkoleń, czyli chętniej szkolą się nauczyciele młodsi. Nauczyciele starsi nie uczestniczą i nie deklarują chęci uczestnictwa $\mathrm{w}$ formach doskonalenia zawodowego związanych z pracą z uczniem cudzoziemskim. Biorąc od uwagę "odwróconą piramidę 
awansu zawodowego nauczycieli", z jaką mamy do czynienia w polskiej edukacji, ten fakt nie zaskakuje. Starsi nauczyciele osiągnęli pułap kariery zawodowej i nie mają motywacji zewnętrznej do podjęcia działań w tym zakresie. Nie dziwi też fakt, że nauczyciele $\mathrm{z}$ wysokim poziomem ekstrawersji deklarują chęć udziału w szkoleniach. Zaobserwowaliśmy także, że nauczyciele o wyższym poziomie neurotyczności $\mathrm{w}$ mniejszej liczbie podejmowali szkolenia w zakresie uczenia dzieci cudzoziemskich. Można byłoby więc postawić hipotezę, że osoby o pewnych profilach osobowości: bliżej bieguna introwersji i bliżej bieguna wysokiej neurotyczności dążą świadomie lub nieświadomie do uniknięcia pracy z dziećmi cudzoziemskimi.

Obecnie jeszcze, kiedy szkoły polskie przyjmują stosunkowo niewielu uczniów cudzoziemskich (choć wcale nie tak mało, jak stereotypowo podaje się w mediach), opisane wyżej zjawisko nie stanowi jeszcze tak wielkiego problemu. Jednakże, w perspektywie zwiększającej się liczby uczniów cudzoziemskich w polskich szkołach wkrótce okaże się, że wszyscy nauczyciele powinni być przygotowani do pracy z uczniem z doświadczeniem migracji. Z naszego badania wynika zatem konieczność doprowadzenia do zmiany postaw wobec szkoleń $\mathrm{w}$ tej dziedzinie u części nauczycieli.

Zaprezentowane badanie, przeprowadzone wiosną 2016 roku, będące pierwszym etapem większego badania - planowanego w kolejnym roku szkolnym 2016/2017 - pomaga lepiej zrozumieć zależności pomiędzy cechami osobowości nauczyciela a pracą z uczniem cudzoziemskim, w celu lepszego zbudowania oferty doskonalenia zawodowego dla nauczycieli, a jednocześnie pozwala na konstrukcję kolejnych pytań badawczych.

\section{BIBLIOGRAFIA}

Andrejuk K., Postawy wobec imigrantów w świetle wyników Europejskiego Sondażu Społecznego 2014-2015. Polska na tle Europy, Zespół Studiów Europejskich, Working Paper 2/2015, Warszawa http://www.ifispan.pl/wp-content/uploads/2015/12/Postawy-wobec-imigrant\%C3\% B3w-w-\% C5\%9Bwietle-wynik\% C3\%B3w-EuropejskiegoSonda \%C5\%BCu-Spo\%C5\%82ecznego-2014-2015.-Polska-na-tle-Europy.pdf [dostęp: 20.03.2016].

Bastion K.C. i in., Do personality Traits Impact Beginning Teacher Performance and Persistence? 2015, http:// www.wcu.edu/WebFiles/PDFs/CEAP_PersonalityTraits_2015.pdf [dostęp: 2.01.2016].

Bergamaschi A., Attitudes et représentations sociales. Les adolescents français et italiens face à la diversité, «Attitudes et représentations sociales», Revue européenne des sciences sociales [En ligne], 49-2 | 2011, mis en ligne le 01 janvier 2015, http://ress.revues. org/996 ; DOI : 10.4000/ress.996 [dostęp: 1.12.2015].

Błeszyńska K.M., Edukacja wobec wyzwań migracyjnych, ORE, Warszawa 2010. www.ore. edu.pl [dostęp: 10.02.2016]. 
CBOS Komunikat z badań BS/12/2013, Warszawa luty 2013: Stosunek Polaków do innych narodów, opracowała Beata Roguska, http://www.cbos.pl/SPISKOM. POL/2013/K_012_13.PDF, [dostęp: 11.05.2016].

CBOS, Komunikat z badań nr 113/2015: Zmiany nastawienia Polaków do innych narodów, opracował Rafał Boguszewski, http://www.cbos.pl/SPISKOM.POL/2015/K_113_15. PDF, [dostęp: 11.05 2016].

Federowicz M., Sitek M., Licza się nauczyciele. Raport o stanie edukacji 2013, MEN, IBE, http:/ / eduentuzjasci.pl/publikacje-ee-lista/raporty/150-raport-o-stanie-edukacji/ 1052-raport-o-stanie-edukacji-2013-licza-sie-nauczyciele.html [dostęp: 30.01.2016].

Goldberg L., Language and Individual Differences: The Search for Universals in Personality Lexicons [w:] Review of Personality and Social Psychology, red. L. Wheeler, Sage Publication, Beverly Hills, CA:1981.

GUS, 2015. Informacja o rozmiarach i kierunkach czasowej emigracji z Polski w latach 2004 2014. http://stat.gov.pl/download/gfx/portalinformacyjny/pl/defaultaktualnosci/5471/11/1/1/szacunek_emigracji_z_polski_w_latach_2004-2014.pdf

Halik T., Migrancka społeczność Wietnamczyków w Polsce w świetle polityki państwa i ocen społecznych, Wydawnictwo Naukowe UAM, Poznań 2006.

IPSOS dla IOM, 2015, Badanie na temat postaw wobec cudzoziemców w Polsce, http://udsc. gov.pl/postawy-wobec-cudzoziemcow-w-polsce/ [dostęp: 18.03.2016].

Konieczna J., Świdrowska E., Młodzież, imigranci, tolerancja. Raport z badań terenowych w szkołach, Towarzystwo Demokratyczne Wschód, 2008. http://tdw.org.pl/galeria/ publikacje/mlodziez\%20imigranci \%20tolerancja/raport $\% 20$ o $\% 20$ szkolach $\% 20$ tdw. pdf [dostęp: 1.03.2016].

Kubin K., Pogorzała E., Raport z badania systemu nauczania dzieci cudzoziemskich języka polskiego jako drugiego/obcego w szkołach w Polsce, Fundacja na rzecz Rozwoju Różnorodności Społecznej, Warszawa 2014 http://ffrs.org.pl/biblioteka/raporty/ [dostęp: 22.02.2016].

Norman W., 1967. 2800 Personality Trait Descriptors: Normative Operating Characteristics For A University Population. The University of Michigan. https://files.eric.ed.gov/fulltext/ED014738.pdf [dostęp: 2.12.2016]

OECD, Creating Effective Teaching and Learning Environments: First Results from TALIS, 2009.

OECD, Les élèves immigrés et l'école. Avancer sur le chemin de l'intégration, 2015. [dostęp: 15.01.16].

Reeves J., Secondary Teacher Attitudes toward Including English-Language Learners in Mainstream Classrooms, Faculty Publications: Department of Teaching, Learning and Teacher Education, 2006, Paper 116. http:/ / digitalcommons.unl.edu/teachlearnfacpub/116 [dostęp: 15.01.16].

Sleeter C.E., Un-standardizing curriculum: Multicultural teaching in the standards based Classroom, New York: Teachers College Press, 2005.

Stefańska R., Szulecka M., Bezpieczny status prawny jako determinanta awansu ekonomiczno-zawodowego odmiennych grup imigrantów w Polsce, Central and Eastern European Migration Review, 2013, 1, s. 91-115, http://www.ceemr.uw.edu.pl/vol-2-no-1-june-2013/ articles/bezpieczny-status-prawny-jako-determinanta-awansu-ekonomiczno [dostęp: 8.05. 2016].

Szarota P., Polska lista przymiotnikowa (PLP): Narzędzie do diagnozy pięciu wielkich czynników osobowości, Studia Psychologiczne, 1995, 33 (1-2).

Szymańska-Matusiewicz G., Vietnamese from Eastern Europe as a Transnational Migrant Community, [w:] The Age of Asian Migration: Continuity, Diversity, and Susceptibility, Volume I, red. Y.W. Chan, D. Haines, J. Lee, Cambridge Scholars Publishing, London 2014. 
Szymańska-Matusiewicz G., The Two Tet Festivals: Transnational Connections and Internal Diversity of the Vietnamese Community in Poland, "Central and Eastern European Migration Review”, 2015(1), http:/ / www.ceemr.uw.edu.pl/vol-4-no-1-june-2015/articles/two-t-t-festivals-transnational-connections-and-internal-diversity [dostęp: 10.05.2016].

Urząd do Spraw Cudzoziemców, Napływ cudzoziemców ubiegających się o objęcie ochrona międzynarodowa do Polski w latach 2009-2015, raport http:/ / udsc.gov.pl/wp-content/ uploads/2015/05/refugee-report.pdf [dostęp: 6.01.2016].

Wysieńska K. (red.), Sprzedawać, gotować, budować? Plany i strategie Chińczyków i Wietnamczyków w Polsce, Instytut Spraw Publicznych, Warszawa 2012.

Zawadzki B.A., Strelau J., Szczepaniak P., Śliwińska M., Inwentarz Osobowości NEOFFI Costy i McCrae. Polska adaptacja. Podręcznik, Pracownia Testów Psychologicznych PTP, Warszawa 1998. 